Article

\title{
Subnational Fiscal Consolidation: The Hungarian Path from Crisis to Fiscal Sustainability in Light of International Experiences
}

\author{
András Bethlendi ${ }^{1,2, *(1)}$ and Csaba Lentner ${ }^{2}$ (1) \\ 1 Department of Finance, Faculty of Economic and Social Sciences, Budapest University of Technology and \\ Economics, 1111 Budapest, Hungary \\ 2 Public Finance Research Institute, Faculty of Science of Public Governance and Administration, \\ National University of Public Service, 1083 Budapest, Hungary; Lentner.Csaba@uni-nke.hu \\ * Correspondence: bethlendi@finance.bme.hu; Tel.: +36-30-923-87-25
}

Received: 19 July 2018; Accepted: 9 August 2018; Published: 21 August 2018

\begin{abstract}
The purpose of this study is to broaden the literature on the factors that contribute to the over-indebtedness of the subnational sector and the related crisis management tools based on the experience of Hungary. In addition to the phenomena known from the literature (vertical imbalance, the fiscal tightening of the central government, the weakness of central control and transparency, and local government-owned companies), non-standard factors also contributed to the evolution of a subnational fiscal crisis in Hungary. The Hungarian municipalities had, in practice, built up a carry trade position for speculative purposes, mostly from Swiss Franc funding. The other relevant observation based on experience is that, when significant amounts of central development funds fail to form a carefully considered development policy, over the long term they could undermine local fiscal stability. In addition to extraordinary fiscal transfer and full assignment of debts, the Hungarian subnational fiscal consolidation also involved a novel technique: the obligations were transferred to the state through the assumption of duties. In Hungary, in line with international experiences, central financial assistance was accompanied by increased fiscal control and by a tightening of the requirements for budgetary transparency and data reporting. Central approval for the assumption of new debts became an important element of fiscal sustainability. In addition to the above, this study argues that in political, social, and legal terms, credible no-bailout regimes do not offer an optimum solution for the subnational sector.
\end{abstract}

Keywords: public finance; subnational; sub-sovereign; municipalities; indebtedness; FX loans; fiscal crises; crises management; consolidation; carry trade

\section{Introduction}

Alongside the indebtedness of the central government sub-sector, the indebtedness of municipalities has also become a frequently seen phenomenon across the world. It is an innate feature of indebtedness that even in the case of conservative and prudent indebtedness events may take place that make it unsustainable. The risk becomes significant when municipalities and regions (collectively referred to as the "subnational sector") run into heavy debt, as it paralyses the functioning of the state and may have a serious impact on the quality of life of the population. This is because these authorities perform a large number of public services, and the impairment of these services carries considerable political and legal risks (right of equal access to public services). For this reason, a phenomenon is seen that is similar to the "too big to fail" problem encountered by financial institutions and can be described as "too sensitive to fail" or "too national to fail". As with the "too big to fail" phenomenon, this engenders a moral risk, in that the wrong incentives 
encourage irresponsible local management, because beyond a certain point the central government will rescue the subnational government concerned.

This study first provides a summary of the factors leading to subnational fiscal crises and subnational debt crisis management tools (Section 2). The literature often does not differentiate between trigger events and the fundamental reasons for subnational fiscal crises. To help prevent new crises, this study identifies the most important fundamental factors which can contribute to subnational fiscal crises. Based on the summarized international experiences, the indebtedness and consolidation of the Hungarian subnational sector are examined. The factors that make the Hungarian subnational crisis and its management non-typical are identified, thus further expanding the literature (Sections 3 and 4). Section 5 provides a conclusion.

Hungary is a located in the post-soviet region and its conversion was supported by its accession to the European Union. Nevertheless, along with the other Central European countries, it was characterized by specific anomalies. For example, decentralization far exceeded the EU average, and thus decreased the effectiveness of the sector. Furthermore, in addition to the corporate sector and central government, households and municipalities in Hungary also took on foreign currency debt, causing major solvency and macro-economic risks. We believe this analysis may serve as a relevant case study for testing the sustainability of subnational indebtedness in other catch-up economies and for the management of excessive debt.

\section{International Experience in Identifying the Factors Contributing to over Indebtedness of the Subnational Sector and Related Crisis Management Tools}

\subsection{Subnational Fiscal Crisis}

The "subnational sector" is a collective concept for the (non-central) levels of state administration below a sovereign government that are assigned certain autonomy in decision-making and public duties. The number of these levels and the autonomy assigned to them may differ by country and by level.

Based on Cordes et al. [1], fiscal crises are characterized by the state or municipality losing the opportunity to (further) raise funds from the market, or facing increased financing costs that prevent it from providing basic services. While sovereign bankruptcy is a relatively frequent phenomenon, it is practically non-existent at a subnational level. In the period between 1950 and 2010, the number of sovereign bankruptcies exceeded a hundred [2]. On the other hand, the only subnational default case was in the United States, where the Federal Government allowed certain states to go bankrupt in the 1840s. Both the sovereign and the subnational levels are characterized by the absence of a generally accepted bankruptcy proceeding or crisis management process. For this reason, sovereign debt crises may be considerably prolonged, have an uncertain outcome, and are costly [3]. On the subnational level, only very few countries have a code to provide distressed municipalities with protection from creditors and to enable them to reach an agreement with their creditors on debt restructuring. In the United States, Chapter 9 of the bankruptcy code is regularly applied in the case of counties (e.g., Orange and Jefferson), states (e.g., California), cities, and minor municipal institutions (e.g., schools and public utility companies). As they do not require central intervention, their crisis management is not discussed.

Two major waves of subnational crises can be distinguished: the period between the 1970s and the late 1990s, and another wave in the wake of 2008. The reasons for subnational fiscal crises can be divided into trigger events and root causes. Trigger events may include interest rate or exchange rate shocks caused by tightening of general (international) financial conditions, or the bankruptcy of a subnational off-budget institution. The literature often does not differentiate in this way, but focuses on trigger events (e.g., [1]). Instead of the latter, this study examines the root causes.

\subsection{Factors Leading to Fiscal Crises}

We have not found any systemic grouping of factors leading to subnational fiscal crises in the literature. Therefore, we have divided the factors into two major groups: central/general and local factors. 


\subsubsection{Central/General Factors}

\section{(1). Liberalization and Deregulation}

Indebtedness and the application of credit financing are not new phenomena in the subnational sector. Local government borrowing became popular with the public administrative and regulatory changes and market liberalization of the 1960s and 1970s. At the same time, numerous central governments made an effort to regulate such borrowing as they recognized that market discipline was insufficient due to information problems (the informational asymmetries of minor entities and the absence of transparency) and the moral risks mentioned below. Market discipline means that the financial market punishes sub-sovereign entities with deteriorating financial standing by charging higher risk premiums in order to discipline their budget. However, certain authors $[4,5]$ still argue today that the market can act as a disciplinary force in this segment if the subnational entities cannot genuinely rely on assistance from the central government, in other words, if they have a hard budget constraint. In the literature this is termed a "credible no bailout" system.

The central regulation of local governments' financial management and the easing or termination of control lead to an increase in local indebtedness, and, in certain cases, to excessive debt. A good example is Australia, where local borrowing and budgetary processes were coordinated and controlled by a central institution (called the Loan Council), which also assumed liability for the local debt portfolios on the financial and capital markets. One of the main purposes of the establishment of this institution was the development of an efficient debt management system. On the international capital market, the territories should have joined forces against their creditors rather than acting separately. The institution of the Loan Council was loosened up in several steps, and from 1990 onwards, the territories were fully liable for their debts. The states started to run into debt; in 1992 the state of Victoria ran into a considerable financing problem [6].

When a soft budget constraint is applied, one of the reasons for the absence of market discipline is described by the so-called risk transfer hypothesis, which states that expectations regarding a central bailout result in lower financing costs and easier access to credit than is justified by the municipalities' own creditworthiness. On the other hand, a considerable debt built up by the subnational sector may also raise sovereign financing costs. Jenkner and Lu [7] proved the operation of the risk transfer hypothesis based on Spanish data. A similar conclusion was drawn by Beck et al. [4] on the basis of an international sample. Based on the risk transfer hypothesis, market processes allow municipalities to run into heavy debt due to reliance on central financial assistance.

\section{(2). Insufficient Transparency Criteria}

Municipalities may perform some of their activities through separate legal institutions. The employment of such institutions enables the municipalities to circumvent the constraints imposed on them to curb their deficit and indebtedness, and the debts thus generated can remain hidden from the central government. In their study, De Vicente Lama et al. [8] demonstrated that the method of taking Spanish municipal businesses into account could have a heavy impact on municipalities' compliance with the financial regulations. They found that the businesses in municipal ownership are capable of converting the budget deficit into an off-budget item, thus making the local government fiscal situation unhealthy.

\section{(3). The Degree of Fiscal Decentralization}

There is a discussion in the literature about whether fiscal decentralization contributes to excessive borrowing by subnational governments, or on the contrary, whether it might ensure the fiscal stability of the public sector by constraining Leviathan governments. For more than two decades the World Bank has supported fiscal decentralization and carried out such projects in several countries. They argue that a carefully implemented fiscal decentralization can decrease political instability and increase government efficiency, since it increases accountability and transparency in service delivery and policy-making. [9] On the other hand, several potential drawbacks of fiscal decentralization have been identified in the literature. 
Beside the already discussed moral hazard problem and soft budget constraint, fiscal decentralization might decrease the ability of central governments to conduct stabilization policies and to redistribute income [10] In addition, it entails coordination failures in intergovernmental fiscal relations, which are likely to create a deficit bias in decentralized policy making, especially in emerging economies [11] Fiscal decentralization as a general concept has several different aspects: expenditure, revenue decentralization, and vertical fiscal imbalances (see separately). Baskaran [12] found that expenditure decentralization significantly reduces general government indebtedness, whereas tax decentralization and vertical fiscal imbalances are insignificant. However, this study does not differentiate between central or subnational borrowing, as it looks at the consolidated effect of the two tiers of government. On the other hand Asatryan at al. [13] found that that greater tax (revenue) decentralization is associated as well with improved sub-national government budget deficits/surpluses.

(4). Major Vertical Imbalance and the Passing on of Central Fiscal Crisis Management to Municipalities

According to the relevant literature, one of the reasons for excessive indebtedness is so-called vertical imbalance (i.e., differences between subnational expenditure and revenue autonomy), if it is more substantial and accompanied by authorization for the local entity to borrow. Subnational governments that do not have large tax incomes are prone to run into heavy debt to maintain their public services [14].

In the absence of sufficient autonomous income, conflict may easily build up between the central government and the local municipalities, if, for instance, the central fiscal crisis management also puts pressure on municipal budgets (transfers and local taxes are cut). In other words, the tightening constraint is passed on to municipalities by curbing their revenues. However, decisions on the expenditure side remains in the hands of municipalities, and consequently, high and permanent subnational deficits, financed from loans, may evolve and create an unsustainable financial situation. This case is illustrated by the following examples:

- In Italy the 1972-1973 tax reform considerably curtailed autonomy over local fiscal incomes. By 1977-1978, numerous municipalities had sunk into a fiscal crisis [6]. After 2008, Italy followed a different approach, and as fiscal austerity was also introduced at the local level, local indebtedness remained broadly unchanged and was accompanied by a severe reduction in public investments [15].

- In Spain after the 2008 global financial crisis, a considerable budget deficit was built up and serious sovereign debt sustainability problems were encountered and followed by a significant budgetary adjustment. The subnational sector's central incomes dropped, but this was not followed by a drastic cut in expenditures. As a result, numerous regions found themselves on the verge of insolvency within three years [7].

\section{(5). Overall Macroeconomic and Sovereign Fiscal Crisis}

Overall macroeconomic crises have a combined negative impact on subnational entities: crisis decreases tax revenues and increases demand for social services. This could be further worsened by the central fiscal cuts. In numerous cases municipalities cannot free themselves from the overall macroeconomic crisis or the fiscal crisis of the central government (see the Swedish, Spanish, and Latin American examples), and thus sovereign and subnational fiscal crises unfold simultaneously. In the worst case scenario, sovereign bankruptcy also bankrupts a proportion of the subnational entities. The literature (e.g., the summary by Cordes et al. [1]) generally mentions examples from Latin America (e.g., Argentina, Brazil). The 1998 Russian financial crisis created a similar situation [16]. Note that the Russian sub-sovereign fiscal crisis received little attention in the literature despite it having been one of the largest sub-sovereign bond markets among emerging economies. 


\subsubsection{Local Factors}

\section{(1). Structural Crisis of the Local Economy}

Diversification is often rather low in local economies (focus on heavy industry, automotive industry, agriculture, etc.), and so their shock resistance is weak. For this reason, an external economic shock affecting the predominant sector may cause a dramatic downturn, reducing municipal revenues. As a considerable proportion of expenditures is spent on fundamental public services that the municipalities endeavour to maintain, if no central assistance is received, the specific subnational entity may face permanent imbalance. Examples include the crisis in Saarland and Bremen in Germany at the end of the 1980s, which was triggered by a decline in heavy industry [6].

\section{(2). Local Policy}

Certain political elements may also influence subnational indebtedness. According to the literature, the level of subnational indebtedness may be influenced by the ideology of the current governing party and the stability of the power of municipal leaders. Based on Spanish data, Vicente Lama et al. [8] found significant correlation between the ideology of the governing party and the extent of indebtedness. Other country studies, for example Seitz [17], who analysed the determinants of subnational deficits in Germany, did not find any significant impact on indebtedness from the political composition of local governments.

The other phenomenon is the debt illusion (a type of fiscal illusions) when local government spending (debt) levels exceed the optimum level because politicians seek political gains to maximize votes, and voters pay no attention to their share in the local government debt. Reliance on debt, rather than tax finance tend to result in a larger indebtedness [18].

In addition to the above the political business cycles at the municipal level (e.g., see French and Portuguese examples $[19,20])$, it can also result in higher level of indebtedness.

\section{(3). Large-Scale Indebtedness of Certain Subnational Institutions}

Municipalities frequently perform development activities and provide services that require major funding (e.g., public housing, public utilities) organized in separate institutions. Coupled with the abovementioned adverse financial market processes (such as hikes in general debt service costs) and with weak transparency (the size of these debts is hidden for a long time), these significant debt portfolios create an unsustainable financial situation. An example is the unsustainable debt portfolio of Swedish home construction companies [6].

\subsection{Tools and Experiences of Crisis Management}

The "too big to fail" problem characteristic of the banking system appears in a different form in the case of excessive subnational indebtedness and debt management. As a country must provide its citizens with public services (e.g., healthcare, education, and housing) irrespective of the size of administrative areas, they cannot afford to allow the bankruptcy of minor municipalities either in the political or in the legal sense, as this would lead to their inability to provide these services. Hagen et al. [6] showed in detail that central debt relief assistance was provided to the two smallest provinces in Germany and the smaller regions and municipalities in Italy. This means that, unlike in the case of the banking system, the reason why central governments rescue municipalities in difficult financial positions is not their size and the resulting systemic risk, but the existence of public services. As Hagen et al. [6] put it, this is a "too sensitive to fail" kind of problem.

Note that Beck et al. [4] argue that in certain cases the "too big to be rescued" phenomenon may also exist in addition to the former. The authors found that the subnational entities, which had a significant economic size relative to the sovereign state paid a higher risk premium. They gave the explanation that, in the opinion of the market, the sovereign state has a limited capacity to reorganize large subnational entities, and this it is incapable of fully rescuing the subnational sector. We disagree with this argumentation 
for two reasons: (1) the experiences obtained from the subnational fiscal crises do not support it (there has never been any case when larger subnational entities were given less help); and (2) for political and economic reasons, the sovereign state can afford even less to allow larger provinces to go bankrupt. The correlation identified by Beck et al. [4] instead represents the risk that in the case of large subnational entities, the success of crisis management is more uncertain and may drag on in time. However, this does not mean that they do not receive central assistance due to their large size.

Another common theory of financial assistance assumes that it includes the political preferences of central decision-makers. In other words, municipalities managed by people of the same or related political parties have easier access to help. The empirical data (Swedish and German) supported this hypothesis in several cases [6].

Regarding the tools used for crisis management, in some cases pre-set crisis resolution frameworks had been available before the crisis. However, the majority of cases were characterized by some kind of a central financial assistance, set up ad hoc in response to the crisis.

\subsubsection{Pre-Set Crisis Management Frameworks}

Only a few countries (e.g., the United States, Spain, and Switzerland) have a system in place to authentically guarantee that central government does not incur any financial liability whatsoever if municipalities become insolvent (this is called "credible no bailout regime" or "hard budget constraint"). These countries pre-set the instruments for managing subnational crises. However, practice shows that even in these countries with credible no bailout regimes certain situations may arise when the central government or higher level government bodies still intervene and consolidate the subnational sector financially (this is what happened in Spain in 2012 and in the US in 1975, when the State of New York provided assistance to New York City). In this sense, this phenomenon can also be termed a type of "too public to fail" problem. Note that the literature has one counter-example to this phenomenon. Despite expectations to the contrary, the Swiss Supreme Court ruled that the Valois canton was not required to rescue the heavily indebted municipality of Leukerbad [21].

In the majority of cases municipalities have a soft budget constraint (i.e., they can more or less rely on central assistance). For this reason, the subnational sector's financial position also affects the credit rating of the central government. The soft budget constraint is frequently characterized by the fact that the crisis management instruments are not predetermined but depend on the particular case.

\subsubsection{Ad Hoc Central Crisis Management Actions}

There are several practices for providing financial assistance to subnational entities in fiscal crisis. These actions can be classified according to the method of financial support, or according to the conditions of their provision.

We differentiate among the following classes of financial support method $[1,6]$ :

- The assumption of a central guarantee or suretyship to secure sub-sovereign debts, which is the least expensive form of intervention if the guarantee is not called on.

- The sovereign government lends to the sub-sovereign entity directly or indirectly (through a state-owned bank). This also includes special techniques such as debt assumption, and the swapping of unmarketable sub sovereign bonds for central bank/government bonds.

- Extraordinary central transfer, even in the long run, to the distressed sub-sovereign entity. This is the most frequently used method of financial assistance. However, this form is the costliest option for the central government because, unlike loans, their repayment is not expected.

In general, central financial assistance is subject to one of the following conditions, or a combination of these conditions, in order to secure the long-term success of consolidation [6]:

- Improvement in fiscal discipline (deficit size, cutting back on expenditures);

- Improvement in budget accounting, transparency, and in data reporting to the central administration; 
- In certain cases, the central government subjected the distressed subnational entity to administrative control for the crisis management period (e.g., a financial crisis manager is appointed to control the distressed subnational entity).

As a result of bad experiences, after the crisis, subnational autonomy was also limited in several cases, and this primarily meant the adoption of administrative controls on new borrowing (in Brazil and Argentina in the 1990s, and in Russia in 2000).

\section{Subnational Indebtedness in Hungary}

\subsection{International Context}

As the subnational sector and finance show a great variety across the world, it is very difficult to make any comparison. Even within Europe despite the European Charter of Local Self-Government and Stability and Growth Pact giving a common framework for fiscal discipline at both national and subnational levels, the historical legacies and characteristics of state structures (federal or unitary countries) result in a great variety in local government functions and finances.

Based on data from the OECD Fiscal Decentralisation Database (covering 22 EU Member States) it is clear that from the late 1990s up to 2007 central indebtedness improved, while federal and local indebtedness nearly stagnated as a percentage of GDP, as Figure 1 shows. Due to the global financial crisis, central and federal debts sharply increased. In the meantime, local borrowing showed a modest growth. This is one of the reasons for most countries to adopt rules to limit local borrowing.

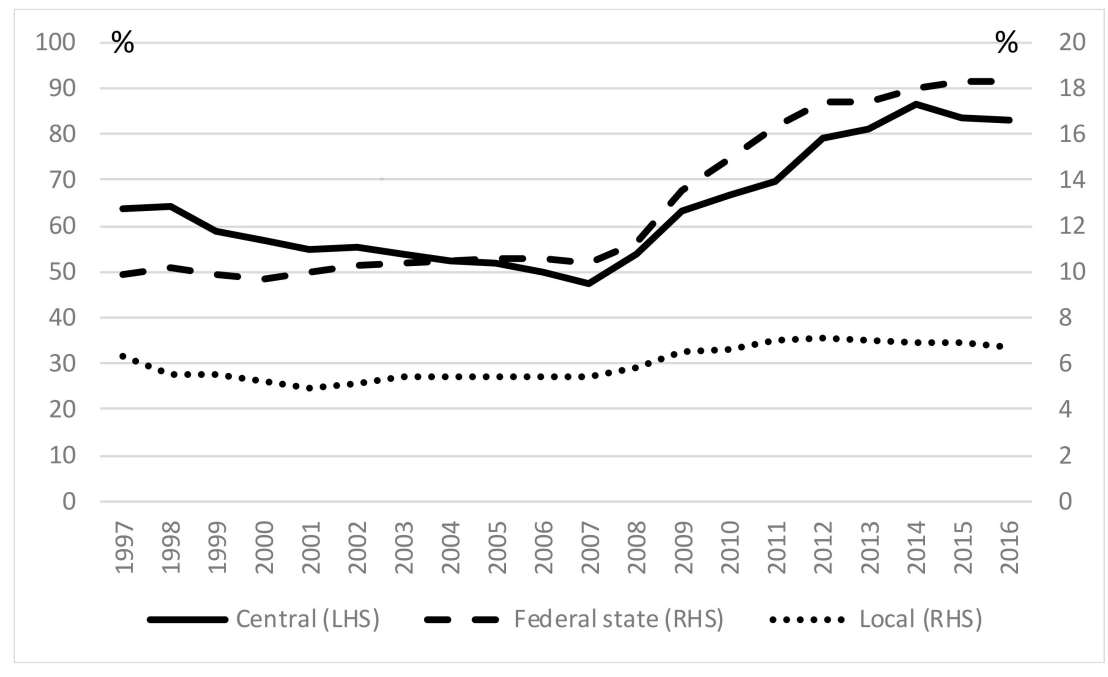

Figure 1. Unweighted average of total EU liabilities as a percentage of GDP (Source: Reference [22], edited by the authors).

Note: left-hand scale of $\mathrm{Y}$ axis represents average debts of EU central governments as a percentage of GDP, while that of federal and local governments is figured out in the right hand scale of $Y$ axis.

Subnational entities are considerably smaller and their autonomy to increase revenues is usually limited compared to central or federal governments. Therefore, it is more relevant to look at debt relative to their revenues, rather than to GDP. Due to the great heterogeneity, in order to achieve a more relevant comparison for Hungary (smaller unitary country with a moderate subnational size), federal countries, countries with tiny or larger subnational sectors (with a ratio of less $2 \%$ or more than 10\% revenue to GDP), and large and/or developed ones (Belgium, France, Italy, Luxemburg, Netherlands, Poland, and UK) have been excluded from the sample. Thus, the following benchmarks were obtained (see Table 1). 
Table 1. Local government debt in unitary countries as a percentage of revenue (Source: Reference [22], edited by the authors).

\begin{tabular}{|c|c|c|c|c|c|c|c|c|c|c|c|c|c|c|c|}
\hline$\%$ & 2002 & 2003 & 2004 & 2005 & 2006 & 2007 & 2008 & 2009 & 2010 & 2011 & 2012 & 2013 & 2014 & 2015 & 2016 \\
\hline Czech Republic & $56 \%$ & $67 \%$ & $64 \%$ & $64 \%$ & $63 \%$ & $51 \%$ & $51 \%$ & $53 \%$ & $57 \%$ & $58 \%$ & $61 \%$ & $59 \%$ & $57 \%$ & $51 \%$ & $51 \%$ \\
\hline Hungary & $42 \%$ & $39 \%$ & $43 \%$ & $51 \%$ & $60 \%$ & $65 \%$ & $105 \%$ & $105 \%$ & $116 \%$ & $106 \%$ & $97 \%$ & $46 \%$ & $15 \%$ & $13 \%$ & $34 \%$ \\
\hline Ireland & $122 \%$ & $135 \%$ & $133 \%$ & $106 \%$ & $117 \%$ & $111 \%$ & $90 \%$ & $66 \%$ & $57 \%$ & $58 \%$ & $59 \%$ & $58 \%$ & $57 \%$ & $63 \%$ & $63 \%$ \\
\hline Latvia & & & $48 \%$ & $50 \%$ & $59 \%$ & $69 \%$ & $81 \%$ & $121 \%$ & $137 \%$ & $136 \%$ & $127 \%$ & $124 \%$ & $132 \%$ & $122 \%$ & $114 \%$ \\
\hline Portugal & $85 \%$ & $96 \%$ & $105 \%$ & $109 \%$ & $108 \%$ & $107 \%$ & $110 \%$ & $129 \%$ & $149 \%$ & $189 \%$ & $188 \%$ & $180 \%$ & $181 \%$ & $168 \%$ & $166 \%$ \\
\hline Slovak Republic & $91 \%$ & $87 \%$ & $85 \%$ & $116 \%$ & $128 \%$ & $139 \%$ & $117 \%$ & $184 \%$ & $208 \%$ & $180 \%$ & $159 \%$ & $138 \%$ & $145 \%$ & $134 \%$ & $138 \%$ \\
\hline Slovenia & $30 \%$ & $27 \%$ & $35 \%$ & $34 \%$ & $32 \%$ & $40 \%$ & $48 \%$ & $57 \%$ & $57 \%$ & $56 \%$ & $56 \%$ & $61 \%$ & $64 \%$ & $61 \%$ & $57 \%$ \\
\hline Other 11 unitary countries (unweighted) & $119 \%$ & $122 \%$ & $126 \%$ & $117 \%$ & $117 \%$ & $121 \%$ & $123 \%$ & $128 \%$ & $133 \%$ & $134 \%$ & $134 \%$ & $135 \%$ & $139 \%$ & $138 \%$ & $138 \%$ \\
\hline 18 EU unitary countries (unweighted) & $101 \%$ & $105 \%$ & $104 \%$ & $101 \%$ & $103 \%$ & $106 \%$ & $108 \%$ & $118 \%$ & $125 \%$ & $125 \%$ & $123 \%$ & $120 \%$ & $121 \%$ & $118 \%$ & $119 \%$ \\
\hline
\end{tabular}


The financial crisis definitely deteriorated the financial position of local governments. However, this fiscal deterioration started well before the crisis, not only in Hungary, but also in certain other countries (Latvia, Portugal, and Slovak Republic) as Table 1 shows (relatively significant rises in indebtedness are highlighted with shadow in the table). The country comparison of local debt sustainability is beyond the scope of this paper. Below we focus on developments in the Hungarian local debt.

\subsection{Unsustainable Hungarian Indebtedness}

In this Section, the indebtedness process of Hungarian subnational entities is described based on the literature overview and analysis of subnational financial data. As a starting point, the main characteristics of Hungarian local government structure are summarized. Hungary is a centralized state, with three levels of elected public administration. There are 3194 local governments. The capital city has a special, dual structure with 23 district municipalities not subordinated to the city government. The Hungarian local government system consists of 19 counties, 23 towns with a county status, 274 cities, 146 villages, and 2708 small villages. Similar to the other countries of the region, the democratic transformation of the former state socialist regime also brought about major changes in the operation of municipalities. By international standards, the average size of Hungarian local governments is relatively small, with only three EU countries having a smaller number of residents per municipality. A significant degree of decentralization was performed; municipalities were given much greater autonomy than is usual in Europe, while the central government also delegated an increased number of duties. This delegation had no justified differentiation, which would have been expected for settlements of different local government levels and sizes. In terms of the organization of services, local governments were responsible for providing the service, therefore there was considerable scope for off-budget performance. The expenditure of local governments amounted to $13 \%$ of GDP, which can be regarded as average in the EU. Hungarian local governments had considerable de jure financial freedom. However, de facto $60-70 \%$ of their funds depended on the annual central budget. In 1996, Hungary introduced a pre-set crisis management framework as a form of local government debt settlement act, making clear that in the case of insolvency there is no state bailout. On the other hand, municipalities in a disadvantaged financial position through no fault of their own were able to receive additional state grants. Therefore, the Hungarian structure was not fully a credible no bailout system [23,24]. In Hungary, the over-extended decentralization created several problems (e.g., many communities could not meet minimum service standards simply because they did not have enough qualified human resources to do so) [25]. Therefore, the local government system was in need of change.

As municipalities were not fully provided with the funds required for the accomplishment of their duties, after the turn of the millennium a permanent operational deficit was generated in the subnational budget. As a general practice, municipalities used development funds and investment loans to finance their operational expenses [26]. The Hungarian subnational sector was characterized by the vertical imbalance known from the literature, and this on its own led to indebtedness. After 2005, this vertical imbalance was further strengthened by the fiscal tightening adopted by the central government, which cut back on the central support for public duties. According to Government Finance Statistics of IMF between 1994 and 2001, the budget balance of the entire Hungarian subnational sector was only able to remain positive due to the income earned on privatization (if adjusted for this, they already showed a deficit already in that period). From 2002 up to 2009, their deficit persisted at $0.35 \%$ of GDP on average [24], which led to continuous indebtedness. The financial stability of the subnational sector is a complex and multidimensional issue (e.g., [27]). However, in our opinion, based on an analysis of the long-term processes of the subnational deficit and financial accounts, a fairly accurate picture can be obtained of financial stability in the sector.

Indebtedness was further increased by the fact that with Hungary's accession to the European Union (in 2004), municipalities had access to significant amounts of EU development funds (in addition to Hungarian development funds) to ensure the infrastructure required for the performance of their duties. Municipalities were required to contribute a certain specified proportion of financing in order to be awarded 
the assistance, and they were not granted any central resources for that purpose. They were usually unable to provide their own resources from their current budget, and so they often funded this from debt.

In numerous cases, the basis of repaying investment loans was invisible at the time of borrowing. For the most part, they spent the support granted by the European Union and the loans they had taken on infrastructure; some of this was purely unproductive investment (e.g., decorative paving of the main square). Hungarian municipalities frequently disregarded the depreciation of the assets created by the investment and the costs of their maintenance [28]. As a peculiarity of infrastructure development, the implemented investment frequently does not directly generate revenues or the revenue made on the investment is insufficient, and thus, to a major extent, municipalities must provide for loan repayment from other sources.

Weak central control and transparency only added to the problems. Insufficient control was partly caused by statutory constraints including, up to 2011, that the State Audit Office was not authorized by law to audit local government companies.

Businesses majority owned by municipalities also piled up significant debt that was invisible in the sector's financial accounts. Municipalities, for their part, did not pay sufficient attention to controlling the indebtedness of their businesses. A situation evolved similar to the one seen in Spain, and the businesses in municipal ownership were capable of converting the budget deficit into an off-budget item.

Developments requiring higher investment-frequently implemented through business organizations in municipal ownership-have also caused fiscal concerns in other countries (e.g. in the Swedish subnational sector). The Hungarian experience shows that, in the absence of a carefully considered development policy, significant central development funds may have the opposite effect in the long term: they can undermine local fiscal stability. To our knowledge this type of risk is not highlighted in the literature.

However, in the two years directly preceding the eruption of the global financial crisis (2007-2008), indebtedness was also characterized by another feature: municipalities spent about a quarter of their long-term funds earned on lending and bond issuance (Hungarian Forint (HUF) 460 billion, approx. EUR 1.8 billion) on the repayment of their other current debts, and invested three-quarters in bank deposits and, to a minor extent, in securities. Specialists explain this phenomenon in several ways [24,29]:

- They allocated foreign exchange (FX) funds obtained at low interest (75\% denominated in Swiss Frank (CHF)) in the form of HUF bank deposits paying higher interests. In 2007 and 2008 the sector's net interest revenues showed a significant increase. The municipalities failed to understand the speculative nature of these transactions, and the short-term interest benefit earned on them further increased local decision-makers' illusions regarding ample liquidity.

- The uncertainty of their future financing position and their fear of a statutory constraints on municipal borrowing prompted them to borrow earlier than scheduled. One of the direct underlying causes was that they wanted to secure the amounts required as own contribution to the funds co-financed by the EU in its development period starting in 2007.

- The sharp competition between banks resulted in strong credit supply and relaxed credit conditions.

Indebtedness also had a technical feature. The overwhelming majority of quick indebtedness took place in the form of bond issuance. However, this was due to a regulatory arbitrage: the issuance of bonds was not subject to an obligatory public procurement procedure as it was for borrowing. The presumption underlying the relevant regulation was probably that tenders cannot be invited for capital market bond issuance, and best practice is easily complied with in this case. Experience showed that no over the counter (OTC) market evolved for these bonds, they remained in the books of the underwriting bank, and so this only constitutes capital market financing in a technical sense. In terms of debt consolidation, the latter proved to be fortunate, as agreement on debt assumption was considerably easier than in the case of genuine bonds traded in the capital market. 
The foreign exchange structure of the debt already posed a systemic risk. A significant share of the loans were denominated in foreign currencies-predominantly in Swiss Francs-although the municipalities did not have any income in foreign currencies. In the case of subnational entities, the literature does not emphasize uncovered foreign exchange lending as involving a significant risk. However, in the Hungarian subnational fiscal crisis, this factor played a key role. Following the eruption of the crisis, the Hungarian currency fell sharply against the Euro and the Swiss Franc, considerably deteriorating subnational balance sheet positions.

The impact of the above factors is clearly visible in the changes of the net financial assets of the Hungarian subnational sector. It is evident that, from the early 2000s, the net financial assets (assets net of liabilities) first declined and then dropped at an accelerated pace, until they became negative in 2010. This change was due primarily to a surge in liabilities, for the most part incurred in FX-loans/bonds. Consequently, the sector's balance-sheet FX position opened considerably as Figure 2 shows.

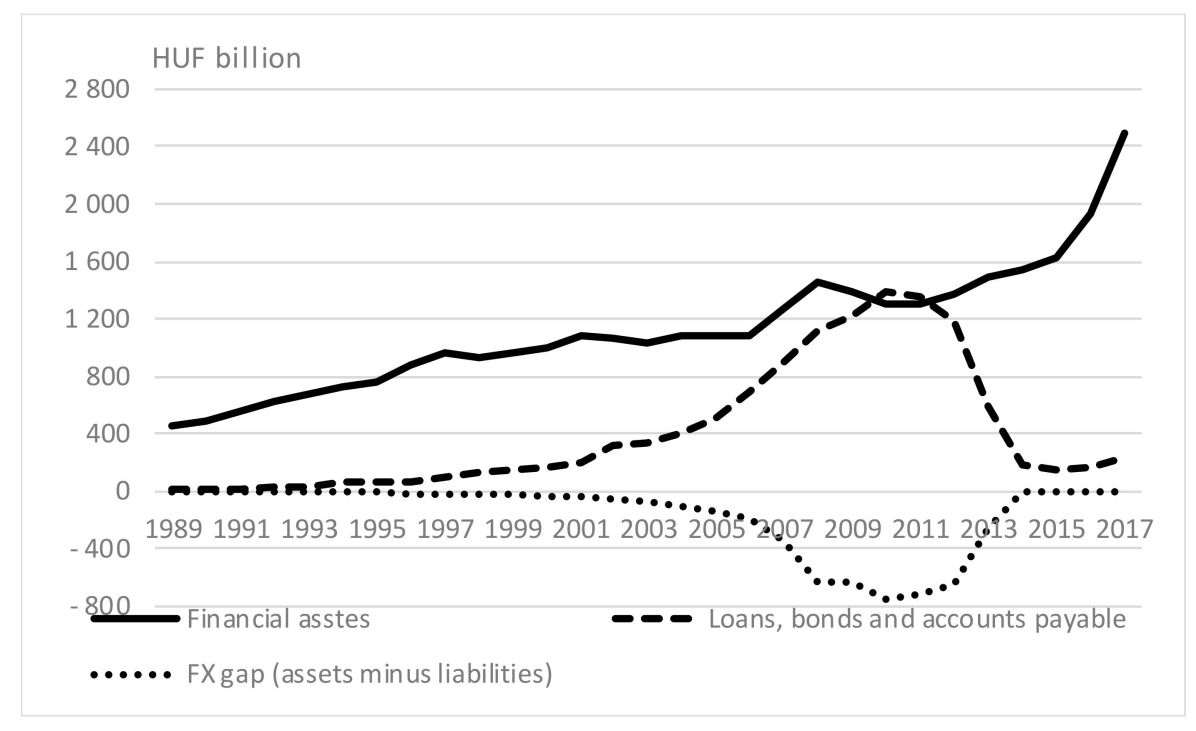

Figure 2. Consolidated financial assets: loans, bonds, and accounts payable of the Hungarian subnational sector, and its open FX-position in the balance sheet (Source: Reference [30], edited by the authors).

As a result of the aforesaid, prior to the 2008 economic crisis, considerable fiscal risks had evolved in the Hungarian subnational sector. Financial instability in the subnational sector affected overall public finances.

The crisis deteriorated the liquidity of municipalities, and there was a shortage of funds for both accumulation and operation. Many municipalities did not have coverage for post-financing the projects implemented with EU subsidies. Due to the ongoing capital investments, at the end of 2010, the sector needed to raise HUF 217 billion (approx. EUR 0.8 billion) from external sources in addition to its own revenues. Municipal liabilities grew primarily because of exchange rate changes and the increasing accounts payable. The increasing debt portfolio became a significant risk because the municipalities failed to accumulate reserves for repayment, and the foreign currency risk made down payment unpredictable, and another risk was run when they offered certain assets constituting registered municipal property as loan collateral [28]. Overall, policy-makers assessed indebtedness as unsustainable.

\section{The Hungarian Debt Consolidation Instrument Mix}

This section utilizes a unique data set: The Municipalities Secretariat of the Hungarian Ministry of the Interior provided detailed information on the consolidation process.

Although Hungary had a pre-set subnational bankruptcy procedure, due to the large number of local governments concerned, a more effective crisis resolution procedure had to be found to replace the individual time-consuming municipal bankruptcy proceedings. As already mentioned, not only 
municipalities, but also the corporate sector, central government, and households had a significant net foreign (FX) debt position. At the end of 2009, the net external debt of the country exceeded $60 \%$ of GDP. Policy-makers aimed to quickly decrease this external fragility of the affected sectors in the middle of the European sovereign crisis. As a result of this policy, the net external debt of the country decreased to $25 \%$ of GDP by the end of 2015 .

The central government managed the subnational debt crisis with the following four steps (Table 2):

- At the end of 2011, the debts of municipalities with county rights were settled with the central government having assumed their duties.

- At the end of 2012, a single, non-refundable transfer was granted to communities with less than five thousand inhabitants to settle their debts.

- In 2013, part of the debts incurred by communities with more than five thousand inhabitants was assumed.

- Finally, in 2014, the remainder of the debt of communities with more than five thousand inhabitants was also assumed.

Table 2. Consolidated amounts and affected municipalities (Source: Reference [26]).

\begin{tabular}{|c|c|c|}
\hline Subnational Entities in the Consolidation & Affected Municipalities (number) & $\begin{array}{l}\text { Consolidated Amount in Billion } \\
\text { HUF (approx. Billion EUR *) }\end{array}$ \\
\hline 2011: county municipalities and the capital city & 20 & 198 (approx. EUR 0.7 billion) \\
\hline $\begin{array}{l}\text { 2013: partial consolidation }(40-70 \%) \text { of the debts of } \\
\text { communities with more than } 5000 \text { inhabitants }\end{array}$ & 279 & 614 (approx. EUR 2.1 billion) \\
\hline Total & 2078 & 1369 (approx. EUR 4.6 billion) \\
\hline
\end{tabular}

Two third of local governments took part in the consolidation, which amounted to approx. EUR 4.6 billion. The total debt assumed in the framework of consolidation was equivalent to 4.2 percent of GDP.

In the middle of 2013, Hungary was released from the European Commission's excessive deficit procedure. It can be seen that the majority of the debt assumption took place after this event. Note that the timing was also convenient in another respect. The sector's open CHF-position was eliminated before another major rise in the Swiss Franc's exchange rate in January 2015, when the Swiss National Bank released the CHF/EUR exchange rate threshold.

The consolidation process may be divided into two parts:

(1). The Assumption of the Debt Portfolios of County Municipalities and the Capital City

In reality, this was not a genuine debt consolidation but the assumption of duties along with the existing liabilities. County municipalities assigned to the state their rights to maintain facilities (e.g., primarily hospitals, specialized clinics, schools, etc.), with full and general legal succession. As the county municipalities only had debts on these institutions, they were exempted from virtually all liabilities. Creditors enforced accounts receivable against the state, and foreign exchange based bonds were assigned to the State Debt Management Centre, while HUF liabilities were assumed by the Hungarian State Treasury. We have not found any other example in the literature when transforming local government duties used as a technique to consolidate subnational fiscal entities.

\section{(2). Genuine Debt Consolidation}

The government applied different techniques to assist municipalities with less than 5000 and those with more than 5000 inhabitants. 
In the case of those with less than 5000 inhabitants, debts were prepaid in practice. The state granted a single, non-refundable budgetary transfer for repayment. This method is in line with the international practices seen so far. The bodies of municipal representatives were required to decide if they wanted the state to assume their debt; every affected municipality requested it. The costs included in the consolidation were regulated in a separate agreement between the Government and the Banking Association. The Hungarian State Treasury transferred the amount of the debts outstanding on the specified date to the municipalities, and they used them for debt repayment.

The state managed the considerably higher debt portfolio of municipalities with more than 5000 inhabitants in a different way: by genuine debt assumption. Standard debt assumption alone only results in a change in the obligor of a legal obligation, in other words, the party who assumes debt replaces the obligor, but this does not represent legal succession with respect to the complete position of the contractual party. For this reason, a trilateral contract (concluded by the bank, the municipality, and the state) was legally required to enable the parties to reach an agreement on the legal succession of the full contractual position, covering all the rights and obligations, by assignment and debt assumption. This is why debt consolidation was preceded by consultation with the banking association and a social dialogue with the municipalities. Debts in foreign exchange were assigned to the State Debt Management Centre and HUF liabilities to the Hungarian State Treasury.

International experiences also showed that central financial assistance was usually accompanied by increased fiscal control and by tightening the requirements of budgetary transparency and data reporting. In certain cases, the municipality's autonomy was also limited. All these elements appeared in the Hungarian crisis resolution:

- In order to improve transparency, task-based financing was adopted in the case of central funds.

- In the interest of increased control over local financial management, the powers and competences of the Hungarian State Audit Office were expanded to cover businesses in municipal ownership.

- The authorization of subnational debt generation was considerably tightened to prevent repeated heavy indebtedness. As a result, since 2014 new borrowing has remained very low (HUF 5 to 20 billion per annum), with the exception of the capital city.

- Simultaneously with debt consolidation, the central government considerably restricted and centralized municipal powers and duties. Within this framework, significant public education, healthcare, and administrative tasks were assigned to the central government. From a fiscal perspective, this reduces possible vertical imbalance and aims to increase the effectiveness of the sector.

The central government's bailout of the municipalities can be considered a manifestation of the soft budget constraint. The Hungarian government wished to mitigate the resulting moral hazard by granting subsidies amounting to HUF 46.8 billion to support the capital investments of the municipalities not involved in the consolidation.

\section{Conclusions}

This study first summarized the factors leading to subnational fiscal crises and subnational debt crisis management tools. The goal was to expand the international experience. The factors that make the Hungarian subnational crisis and its management non-typical have been identified, further adding to the literature.

The study has discussed that in political, social, and legal terms, credible no-bailout regimes do not offer an optimum solution for the subnational sector. The reason for this is that the fiscal crises caused by excessive indebtedness paralyze state operation and affect the quality of life of the population. As subnational authorities provide a considerable amount of public services, their paralysis involves major political and legal risks (right of equal access to public service). For this reason, a phenomenon appears other than that of "too big to fail" seen in financial institutions; it can be described as "too sensitive to fail" [6] or "too public to fail". 
In Hungary, the democratic transformation of the former state socialist regime also brought about major changes in the operation of municipalities. Significant decentralization was undertaken, which entailed the vertical imbalance known from the literature, and this alone led to indebtedness. After 2005, this vertical imbalance was further increased by the fiscal tightening of the central government, which cut back on the central support to public duties.

Weak central control and transparency only added to the problems. Insufficient control was partly caused by statutory constraints. Up until 2011, the Hungarian State Audit Office was not authorized by law to audit local government companies. Similar to the Spanish experience, the businesses in the ownership of Hungarian municipalities were also suitable for converting the budget deficit into an off-budget item.

The Hungarian experience demonstrated a new factor, which can undermine local fiscal stability: in the absence of a carefully considered development policy, significant central development funds may have the opposite fiscal destabilization effect over the long term.

In the two years directly preceding the crisis, the Hungarian municipalities exploited regulatory arbitrage possibilities; instead of borrowing through public tenders they preferred bond issuance, which is not subject to public procurement processes. However, to a large extent this kind of fund raising was for speculative purposes rather than for specific development needs. The Hungarian municipalities had, in practice, built a carry trade position. They borrowed long-term loans denominated in foreign exchange (predominantly CHF) and bearing low interest rates, and invested them in higher-interest HUF assets. In the case of subnational entities, the literature does not emphasize uncovered foreign exchange lending as involving a significant risk and we did not find any other example of lending for such speculative purposes. However, these factors played a key role in the Hungarian subnational fiscal crisis.

The Hungarian government applied a specific mix of instruments to clean up the financial accounts of the subnational sector in several steps, thus eliminating their significant open FX-position. The total debt assumed in the framework of consolidation amounted to 4.2 percent of GDP.

In addition to extraordinary transfers and debt assumption, a novel technique was used for the purpose of fiscal consolidation. The obligations were transferred to the state through the assumption of a significant amount of duties with full and general legal succession. Debts in foreign exchange were assigned to the State Debt Management Centre, and HUF liabilities to the Hungarian State Treasury.

In Hungary, in line with international experiences, central financial assistance was accompanied by increased fiscal control and by the tightening of the requirements for budgetary transparency and data reporting. In the case of new debts, the elaboration of the central authorization scheme should be highlighted. Experience shows that without such rules, the fiscal stability and sustainability of municipalities cannot be ensured over the long term.

Author Contributions: Both authors have contributed equally to the development of this paper A.B. conceptualized the analysis and arranged the international literature. C.L. contributed substantially to the analysis of results and provided overall guidance for the project. All authors have read and approved the final manuscript.

Funding: This research received no external funding.

Acknowledgments: C. Lentner did his research with support from the PADA Leader Expert Program, founded by the National Bank of Hungary. We would like to express our gratitude to three anonymous persons who have significantly improved the quality, clarity, and structure of this paper with their constructive comments. The authors are the only ones responsible for any errors in the paper.

Conflicts of Interest: The authors declare no conflict of interest. 


\section{References}

1. Cordes, T.; Guerguil, M.; Jaramillo, L.; Moreno-Badia, M.; Ylaoutinen, S. Subnational Fiscal Crises. In Designing a European Fiscal Union: Lessons from the Experience of Fiscal Federations; Carlo, C., Martine, G., Eds.; Routledge: London, UK; New York, NY, USA, 2015.

2. IMF: Sovereign Debt Restructuring-Recent Development and Implications for the Fund's Legal and Policy Framework. Staff Paper. Available online: https://www.imf.org/external/np/pp/eng/2013/042613.pdf (accessed on 19 August 2018).

3. Bethlendi, A. Sovereign defaults and how to handle them: Global economic order vs. national economic policy interests-The examples of Greece, Hungary and Ukraine. Civic Rev. 2018, 14, 93-113. [CrossRef]

4. Beck, R.; Ferrucci, G.; Hantzsche, A.; Rau-Goehring, M. Determinants of Sub-Sovereign Bond Yield Spreads: The Role of Fiscal Fundamentals and Federal Bailout Expectations. ECB Working Paper Series No. 1987. Available online: https: / / ssrn.com/abstract=2910899 (accessed on 19 August 2018).

5. Kornai, J. A Puha Költségvetési Korlát (Soft Budget Constraint); Kalligram Publisher: Budapest, Hungary, 2014.

6. Von Hagen, J.; Bordignon, M.; Grewal, B.S.; Peterson, P.; Seitz, H.; Dahlberg, M. Subnational Government Bailouts in OECD Countries: Four Case Studies No. 3100. Research Department Publications from Inter-American Development Bank. Available online: https://ideas.repec.org/p/idb/wpaper/3100.html (accessed on 19 August 2018).

7. Jenkner, E.; Lu, Z. Sub-National Credit Risk and Sovereign Bailouts—Who Pays the Premium? IMF Working Paper, WP/14/20; IMF: Washington, DC, USA, 2014.

8. Vicente Lama, M.; Cordobés Madueno, M.; Torres Jiménez, M. To what extent should public corporations be consolidated? Considering the effects on public deficit and debt in Spanish municipalities. Transylvanian Rev. Admin. Sci. 2017, 52, 148-164. [CrossRef]

9. World Bank. Independent Evaluation Group: Decentralization in Client Countries; An evaluation of World Bank Support, 1990-2007; Technical Report; World Bank: Washington, DC, USA, 2008; Available online: https: / / openknowledge.worldbank.org/handle/10986/6543 (accessed on 19 August 2018).

10. Musgrave, R.M. The Theory of Public Finance; McGraw-Hill: New York, NY, USA, 1959.

11. De Mello, L.R. Fiscal decentralization and intergovernmental fiscal relations: A cross country analysis. World Dev. 2000, 28, 365-380. [CrossRef]

12. Baskaran, T. On the link between fiscal decentralization and public debt in OECD countries. Publ. Choice 2010, 145, 351-378. [CrossRef]

13. Asatryan, Z.; Feld, L.P.; Geys, B. Partial fiscal decentralization and sub-national government fiscal discipline: Empirical evidence from OECD countries. Publ. Choice 2015, 163, 307-320. [CrossRef]

14. Rodden, J. The Dilemma of Fiscal Federalism: Grants and Fiscal Performance around the World. Am. J. Polit. Sci. 2002, 46, 670-687. [CrossRef]

15. Guarini, E.; Pattaro, A.F. Deficit control and fiscal austerity in the EU: Time to consider the local impact. Int. J. Electr. Power Energy Syst. Eng. 2016, 2, 348-369.

16. Litwack, J. Subnational Debt. The Case of the Russian Federation. In Subnational Debt Management and Restructuring; Lessons from International Experience; Kahkonen, S., Gooptu, S., Eds.; World Bank: Washington, DC, USA, 2015; Available online: http://documents.worldbank.org/curated/en/814051468001487842/ Subnational-debt-management-and-restructuring-lessons-from-international-experience (accessed on 20 August 2018).

17. Seitz, H. Fiscal policy, deficits, and politics of subnational governments: The case of the German Länder. Publ. Choice 2000, 102, 183-218. [CrossRef]

18. Oates, W. On the Nature and Measurement of Fiscal Illusion: A Survey. In Taxation and Fiscal Federalism: Essays in Honour of Russell Mathews; Brennan, G., Grewel, B.S., Groenewegen, P., Eds.; National University Press: Sydney, Australia, 1988.

19. Foucault, M.; Madies, T.; Paty, S. Public spending interactions and local politics. Empirical evidence from French municipalities. Publ. Choice 2008, 137, 57. [CrossRef]

20. Veiga, L.G.; Veiga, F.J. Political business cycles at the municipal level. Publ. Choice 2007, 131, 45-64. [CrossRef] 
21. Feld, L.P.; Kalb, A.; Moessinger, M.D.; Osterloh, S. Sovereign Bond Market Reactions to Fiscal Rules and No-Bailout Clauses-The Swiss Experience; ZEW Discussion Paper No. 13-034; Zentrum für Europäische Wirtschaftsforschung GmbH (ZEW): Mannheim, Germany, 2013; Available online: http:/ / ftp.zew.de/pub/ zew-docs/dp/dp13034.pdf (accessed on 20 August 2018).

22. OECD Fiscal Decentralisation Database. Available online: http://www.oecd.org/tax/federalism/fiscaldecentralisation-database.htm\#A_Title (accessed on 7 August 2018).

23. Vígvári, A. Is the conflict container full? Problems of fiscal sustainability at the local government level in Hungary. Acta Oeconomica 2010, 60, 49-77. [CrossRef]

24. Vígvári, A. Atipikus önkormányzati eladósodás Magyarországon (Non-standard indebtedness in Hungary). Közgazdasági Szemle 2009, 7-8, 709-730.

25. Dethier, J.J. The effectiveness of decentralization in Hungary and Slovakia. In Proceedings of the IMF Conference on Decentralization: Experience, Issues and Policies, Washington, DC, USA, 20-21 November 2000; Available online: https:/ / pdfs.semanticscholar.org/1cbf/ffb46015d1f8a809de4c32cece618193144a.pdf (accessed on 20 August 2018).

26. Lentner, C. The Debt Consolidation of Hungarian Local Government. Publ. Finance Quant 2014, 3, 310-325.

27. Bolívar, M.P.R.; Galera, A.N.; Muñoz, L.A.; Subires, M.D.L. Analyzing Forces to the Financial Contribution of Local Governments to Sustainable Development. Sustainability 2016, 8, 925. [CrossRef]

28. Hungarian State Audit Office: Összegzés a Helyi Önkormányzatok Pénzügyi Helyzetének és Gazdálkodási Rendszerének 2011. évi Ellenőrzéseiről. (Summary of the 2011 Audits of the Financial Situation and Economic Management of Local Governments) Report 1282 of the State Audit Office. 2012. Available online: https: / www.asz.hu/storage/files/files/\%C3\%96nkorm\%C3\%A1nyzati\%20jelent $\%$ C3\% A9sek/1282j000.pdf?ctid=269 (accessed on 20 August 2018).

29. Homolya, D.; Szigel, G. Önkormányzati Hitelezés-Kockázatok és Banki Viselkedés. (Lending to Municipalities—Risks and Banking Behaviour). MNB Bulletin, National Bank of Hungary, Budapest, Hungary) September 2008. Available online: https:/ / www.mnb.hu/letoltes/homolya-daniel-szigel-gabor.pdf (accessed on 20 August 2018).

30. National Bank of Hungary, Full Set of Financial Accounts (Including All Sectors). Available online: http:/ / www.mnb.hu/en/statistics/statistical-data-and-information/statistical-time-series/xii-financialaccounts-financial-assets-and-liabilities-of-institutional-sectors / full-set-of-financial-accounts-includingall-sectors (accessed on 10 June 2018). 